\title{
Effect of Alpha-Lipoic acid on Pancreatic Optic Atrophy 1 (OPA1) Gene Expression in Male Rat Model of Obstructive Cholestasis and Cirrhosis
}

\author{
Khosrobakhsh Farnoosh ${ }^{1}$, Moloudi Mohammad Raman ${ }^{2}$., Shoja Khatere ${ }^{3}$., Mohammadi Sahel ${ }^{3}$ \\ 1. Assistant Professor, Department of Biological Sciences, Faculty of Sciences, University of Kurdistan, Sanandaj, Iran.,Tel: +98- \\ 87-33664600, f.khosrobakhsh@uok.ac.ir, ORCID CD:0000-0002-7250-4537 \\ 2. Assistant Professor, Liver \& Digestive Research Center, Research Institute for Health Development, Kurdistan University of \\ Medical Sciences, Sanandaj, Iran. \\ 3. MSc Molecular biology, Department of Biological Sciences, Faculty of Sciences, University of Kurdistan, Sanandaj, Iran.
}

\section{ABSTRACT}

Background and Aim: Cholestasis is characterized by blockade of bile flow from the liver to the intestine, which leads to accumulation of bile acids within liver and plasma; it is associated with metabolic disorders and cause hepatocellular necrosis and apoptosis during cholestatic liver diseases. Mitochondria are critical cellular organelles that produce most of the cellular energy. Mitochondrial morphology varies from an interconnected filamentous network to isolated dots. These processes are called mitochondrial fission and fusion. Disrupted mitochondrial morphology has been observed in cholestatic liver disease. Optic Atrophy 1 (OPA1) is one of the proteins involved in mitochondrial fusion and plays an anti-apoptotic role. The aim of this study was to evaluate the effect of $\alpha$-lipoic acid (LA) on OPA1 gene expression in pancreas of rat after bile duct ligation (BDL).

Materials and Methods: Thirty-six male Wistar rats were randomly divided into six groups each containing six rats including: control, sham-operated, cholestatic, cholestatic+LA, cirrhotic, and cirrhotic+LA. After 14 days in cholestasis groups and six weeks in cirrhosis groups, serum samples and liver and pancreas tissue samples prepared for total bilirubin assays, histopathological analysis and pancreatic OPA1 gene expression evaluation by Real-time PCR technique. Total bilirubin data and gene expression data were analyzed by one-way ANOVA and Kruskal-Wallis statistical tests.

Results: The results revealed that serum levels of total Bilirubin were significantly increased in BDL groups as compared with the control and sham operation groups $(P<0.0001)$. Concerning histology, the inflammation Symptoms and tissue necrosis were noted with BDL group. These symptoms were reduced by lipoic acid treatment in the cholestatic group. The result of pancreatic OPAl gene expression showed the significant increase in cholestatic rats and significant decrease in cirrhotic groups as compared with other groups $(P<0.05)$. In cholestatic group, restoring the expression of $O P A 1$ gene was shown in the presence of lipoic acid.

Conclusion: Changing OPA1 gene expression in obstructive rat suggest the causal role of mitochondrial dynamics in pathogenesis of cholestatic disease. In this study, the effect of lipoic acid in OPA1 mRNA level reflects implications of oxidative stress in signaling pathway of cholestasis.

Keywords: Pancreas, Bile Duct Ligation, Mitochondrial dynamics, OPAl gene, Lipoic acid

\section{Received:April7,2019 Accepted:Aug26,2019}

How to cite the article: Khosrobakhsh Farnoosh., Moloudi Mohammad Raman., Shoja Khatere, Mohammadi Sahel. Effect of Alpha-Lipoic acid on Pancreatic Optic Atrophy 1 (OPA1) Gene Expression in Male Rat Model of Obstructive Cholestasis and Cirrhosis. SJKU 2019; 24 (5): 120-134

Copyright (C) 2018 the Author (s). Published by Kurdistan University of Medical Sciences. This is an open access article distributed under the terms of the Creative Commons Attribution-Non Commercial License 4.0 (CCBY-NC), where it is permissible to download, share, remix, transform, and buildup the work provided it is properly cited. The work cannot be used commercially without permission from the journal. 


\section{اثر ليّوئيك اسيد بر بيان ثن يروتئين آتروفى بينايى نوع ا بانكراس در مدل انسدادى كلستاز و سيروزى موش \\ صحرايى نر

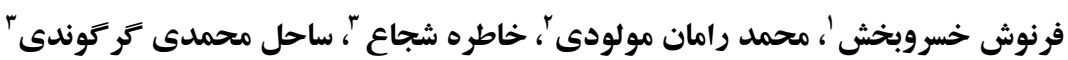

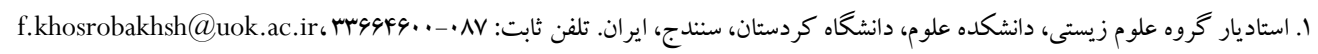

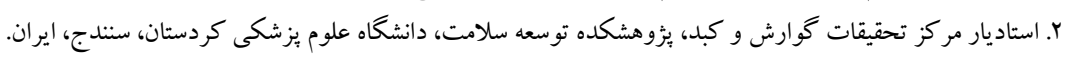

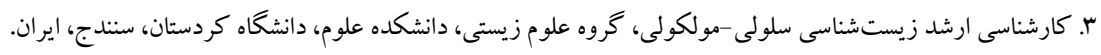

جـكيله

زمينه و هدف: در بيمارى كلستاز انسداد جريان صفرا از كبد به روده منجر به تجمع اسيدهاى صفراوى در كبد و بروز نارسايىهاى متابوليكى شـده

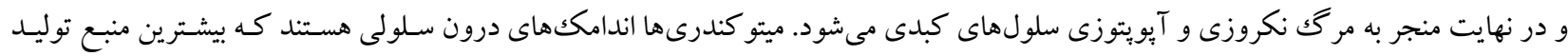

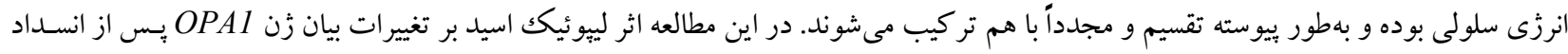

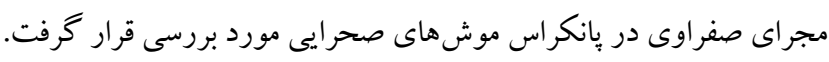

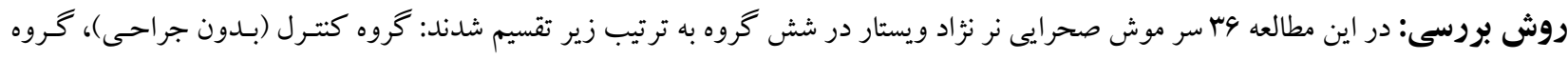

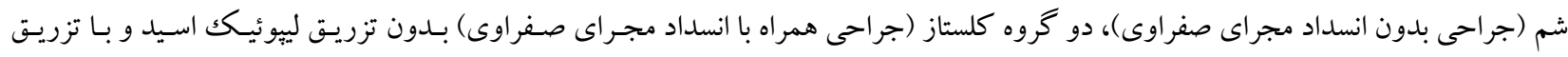

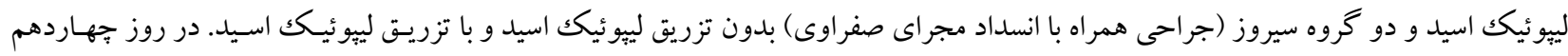

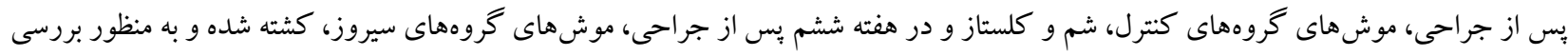

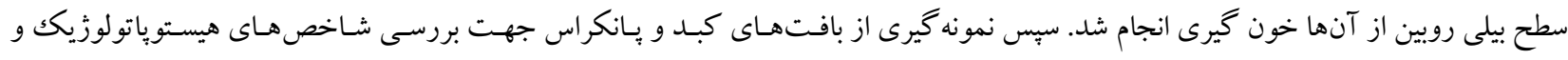

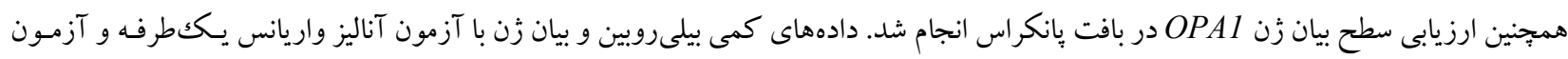
كروسكال_واليس مورد بررسى قرار خرفتند.

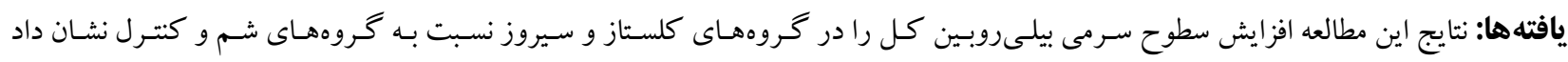

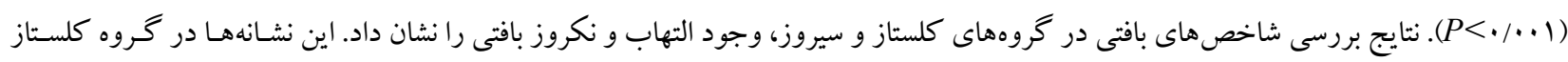

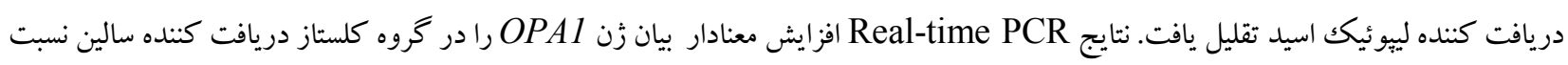

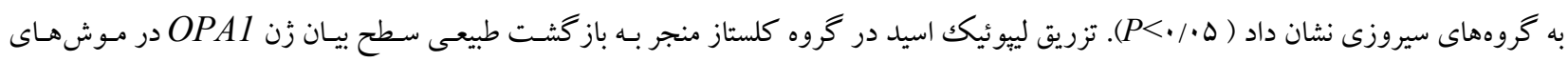
كلستازى شد.

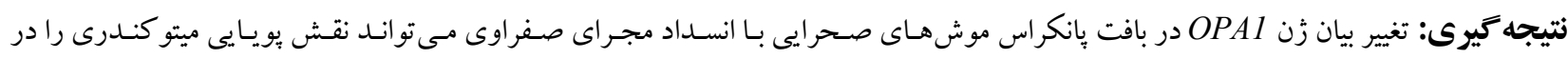

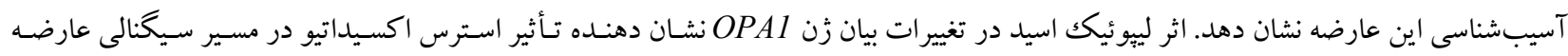
كلستاز است. كليد وازهها: پانكراس، انسداد مجراى صفراوى، يويايى ميتو كندرى، زن :OPA1، لييوئيك اسيد

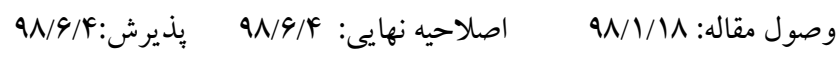


آلفــــ-كتواسـيد دهيــدروزناز شــناخته مسى شــود و خــواص آنتى اكسيدانى دارد. اثرات محافظتى و آنتىاكسيدانى اين ماده در كاهش آسـيبهـاى ناشى از انسـداد مجراى صـفراوى در كبد، روده و سيستم عصبى موشهـاى BDL نشـان داده شـده

$$
\text { است (r, ( ) ( }
$$

نقش ميتو كندرى در آسيبشناسى كلستاز حائز اهميت است و

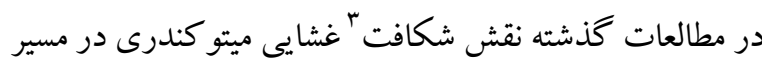

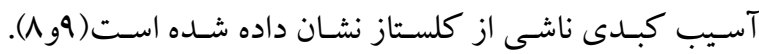
فر آيند هم جوشى " غشاى داخلى و حفظ ساختار تيغه هاى ميانى آنى

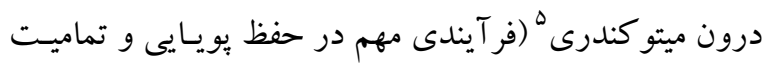
عملكرد ميتو كندرى) را يروتئينى بهنام OPA1 بـه عهـد مئم دارد. اين بروتئين متعلق به خانو اده يرو تئين هـاى داينـامين اسـت كـهـ

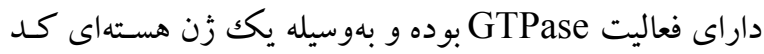
مىشود. جهشهاى زن كد كننده ايسن بـروتئين مسـئول ايجـاد

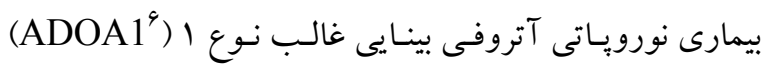
mRNA است (•). زن OPA1 بهطور دائمى و با سطع بيـان

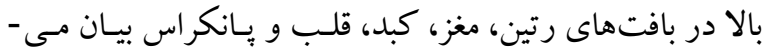
شود(س|-11). در سطح بروتئين نيز، فرم بـيشساز آن و فرم-

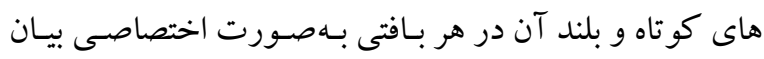
مىشوند(fاوسا). از آنجايى كه اين يروتئين در حفظ سـاختار تيغه هاى ميانى درون ميتو كندرى دخالت دارد، جهشهـاى زن OPA1

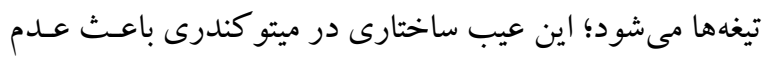

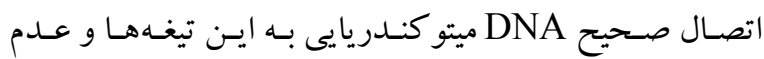
همانندسازى صحيح آنها و در نهايـت تخريـب واكنش هـاى فسفريلاسيون اكسيداتيو و نقص انرزتيكى شـود(ها (1). عملكرد دهرد

${ }^{2}$ Thioctic acid

${ }^{3}$ fission

${ }^{4}$ fusion

${ }^{5}$ Cristae

${ }^{6}$ Type 1 dominant optic atrophy
مقدمه

كلستاز تجمع غيرطبيعى اسـيدهاى صـفراوى اسـت كـه در اثر نقص در فرايند انتقال اسيدهاى صفراوى از كبد به روده ايجـاد مى شود و منجر به باقى ماندن و تجمع اسيدهاى صفر اوى بالقوه

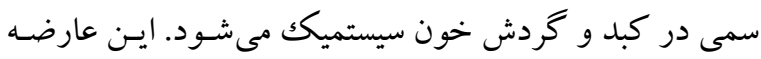
مسىتوانــد در اثـر عوامـل مختلفـى از جملـه: التهـاب، عفونـت

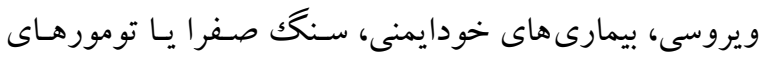
يانكراس، كبد يا درخت صفراوى ايجاد شود( (1). ايـن بيمـارى موجب تجمع داخل سلولى اسيدهاى صفر اوى مى شـود كـه بـهـ

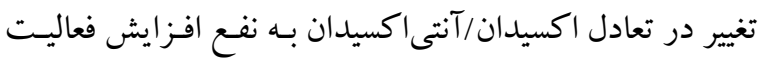
راديكال هاى آزادو و آسيب بافتهاى مختلـف از جملـه كبـد و روده مىانجامد(Y). در كلستاز، باسخ التهابى، افزايش آيويتوز،

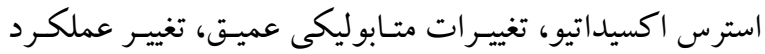

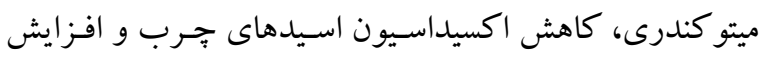

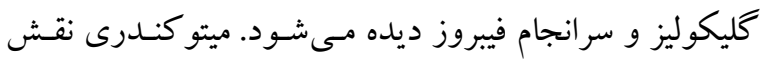

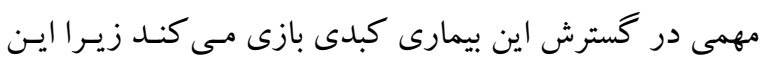

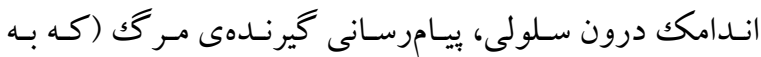
واسطهى سيتو كين هـاى التهابى يـا اسـيدهاى صـفر اوى بـهـ راه مى افتد) را ميانجى كرى مى كند و در آسيب اكسيداتيو، اختلال

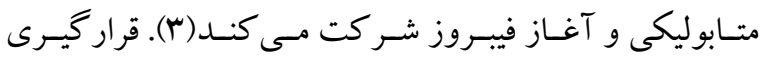
يانكراس در معرض اسيدهاى صفراوى يكى از دلايل احتمـالى

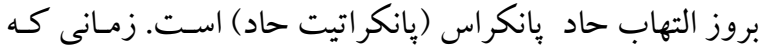

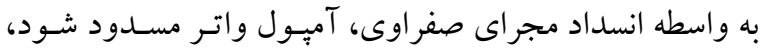

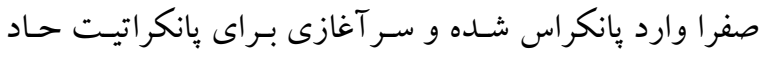

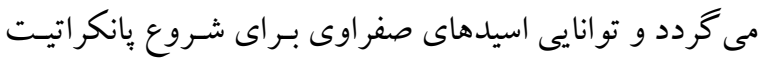
حاد در مطالعات بسيارى تائيد شده است (9-4).

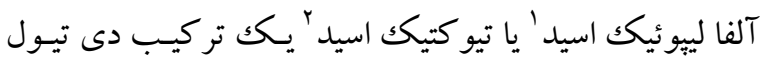
طبيعى است كه بهعنوان كوفاكتور در كميلكس ميتو كندريايى

${ }^{1}$ Alpha-lipoic acid

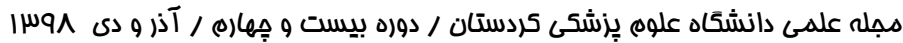


حيوانات: در اين تحقيق تجربى از 4س سـر مـوش صـحرايى نـر نزاد ويستار در محدوده وزنى ه •ا ماه به صسورت تصـادفى اسـتفاده شـده اسـت. حيوانـات در حيوانخانه دانشكده علوم دانشگاه كردستان با دسترسى كـافى به آب و غذا، درجه حرارت Y YF د درجه سانتى گر اد، درجـه رطوبـت وزنسىه 土 ·و درصسد و دوره روشـنايى -تـاريكى ساعته نكهارى شدند. حيوانات به صورت تصـادفى بـه شـش كروه (n=9) (9) كنترل(بدون جراحسى) ، شـم (عمل جراحسى بدون انسداد مجراى صفراوى) ، تيمار شده با سـالين، كلسـتاز تيمار شده با سالين، كلستاز تيمارشده با لييوئيك اسـيد، سـيروز تيمارشده با سالين و سيروز تيمارشده با لييوئيكك اسـيد تقسيم

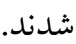
اخلاق: تمام آزمـايشهـا بــر اسـاس مـوازين اخلاقى رفتـار بـا حيوانات، مصوبه كميته رعايـت اخـلاق بزشـكى در مطالعـات تجربى معاهده هلسينكى انجام شد. جراحى: در ابتدا، گروههـاى شــم، كلسـتاز و سـيروز بـا تزريـق داخل صفاقى كتـامين -زايلازيسن (بـه ترتيـب بـه ميـزان •هـ و ه ميلى گرم بـه ازاى هـر كيلـو گرم وزن بـدن) بـىهـوش و ناحيسه شكمى تراشيده و ضدعفونى شد. يوست حفـره شـكمى را بـاز كرده و بعد از ييدا كردن مجراى مشتر كك صفراوى، اين مجـرا در گروه شم بدون ايجاد انسداد، به سر جـاى خـود بر زردانـده شد و در كروه كلستاز و سيروز، قسمت بـالا و يـايين مجـراى صفراوى توسط دو كره به فاصلهى حدود نيم سانتى متر از هـم مسدود شد. سبس جدار شكم در دو لايه عضله و يوست با نخ مخصوص جر احسى بخيـه شـد و يسس از اتمـام عمـل جراحس، ميزان يكك ميلىليتـر سـرم فيزيولوزيـك داخـل صـفاق تزريـق

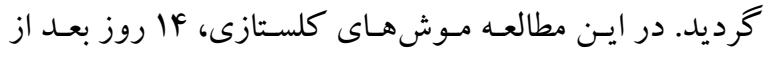
جراحى(V) و موش هاى سيروزى، شـش هفتـه بعـد از جراحسى مورد ارزيابى قرار گرفتند(19).
ديكرى كه در سلول به يروتئين OPA1 نسبت داده شده اسـت اثر ضد آيويتوزى است كه در حقيقت با كنترل ساختار منسجم غشــاء داخلـى ميتو كنـدرى و تيغسههـاى ميـانى از آزاد شــدن سيتو كروم C و بروز آيويتوز جلو گيرى مى كند (19). مطالعات متعددى در گير بودن يويايى ميتو كندرى رادر ترشح انسولين سلولهاى يّانكراس و بروز ديابت نوع ب نشان دادهانـد. در يكى از اين مطالعات نشان داده شده كـه دسـت كـارى بيـان زن اصلى در گير در شـكافت غشـاى ميتو كنـدرى (Drp1) در سلولهاى ترشح كنتـده انسولين يـانكراس مـوش صسحرايى و موش سـورى منجـر بـه تغييـر سـطح يسروتئينهـاى هــمجوشى ميتو كندرى مانند ميتوفيوزن ا و Y و OPA1 و تغيير سـاختار و

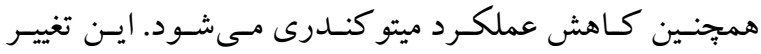
عملكرد، بهصورت تغيير يتانسيل غشاء سـلول و كـاهش توليـد انرزى نمايان مىشود كه در نهايت بر ميزان ترشح انسولين ايسن سلولها تأثير مى كذارد(IV). در سلولهـاى يـانكراس در عـدم حضور بيروتئين OPA1 كاهش قابل توجـه فعاليـت كمـيلكس زنجيره انتقال الكترون ديده مىشود كه ايسن امـر منجـر بـه كاهش توليد انرزى در اين سلولها مىشود (1) . بـا توجـه بـه نقـش يـروتئين OPA1 در عملكـرد زنجيــره انتقـال الكتـرون و توليد كونه هاى فعال اكسيزن توسط اين زنجيره، براى شـناخت جايخـاه بيـان ايسن زن در آسـيب اكسـيداتيو كلسـتاز در بافـت يانكراس كه نقش متابوليكى حساسى را به عهده دارد، در ايسن يثو هش با انجام عمل جراحى انسداد مجراى صفر اوى مشتر كى بر روى موش صحرايى، مــل حيـوانى بيمـارى كلسـتاز ايجـاد

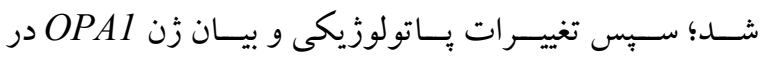
موشهاى كلستازى و سـيروزى تيمـار شـده بـا ليجيوئيكك اسـيد مورد بررسى قرار كرفت.

مواد و روشها

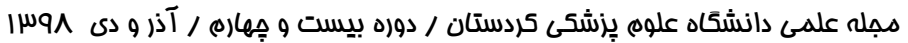




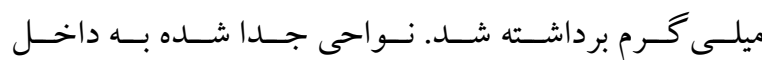
ميكروتيـو بـهــاى عـارى از نو كلئـاز كــه حسـاوى محلــول RNAlater محلول RNAlater بلافاصله به فريزر •V- درجه سـانتى گر اد منتقل شدند و بعد از YF ساعت نكهدارى در اين دما استخراج RNA بافت يانكراس گروههاى آزمايشى شم، دو گروه كلسـتاز و دو كروه سيروز جدا شده و در فرمالين ده درصد تثبيت شدند. اسـتخراج RNA از بافـت بـانكراس : اسـتخراج RNA كـل از innuSOLV مونسههـاى يـانكراس بـا اسـتفاده از محلـول RNA كـار بــرده شـده در مطالعـه بيشـين مـا انجـام شـد( (Y). روش استخراج RNA به اين صـورت بـود كـه ميكروتيـوب حساوى بافت در ازت 199 ـ قرار داده شد. ستيس به كمكك يسـتل بافت

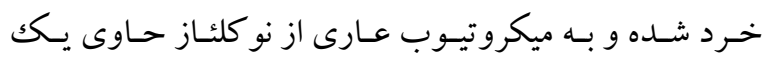
ميلى ليتر محلول innuSOLV RNA منتقل شـد و بـه كمـك

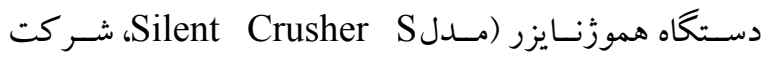
هايدولف، آلمان) بهطور كامـل همـوزن شــــ ســس بـا اضـافه كردن كلروفرم و انجام مراحل سانتريفيوز ميكروتيوبهـا، سـه لايه شفاف، سفيد و كدر تشكيل شد. فاز آبكى شفاف توسط

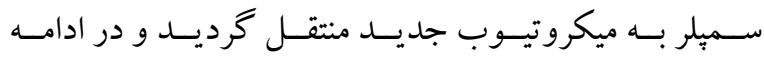
ايزويرويانول سرد و اتـانول بـه منظور رسـوب دهى RNA و جداسازى RNA ى كل اضافه شد. در نهايـت خشـك كـردن رسوب و حـل كـردن رسـوب بـا آب تيمـار شـده بـا دى اتيـل ييروكربنـات لو مهـار كنتـده آنزيم RNase انجـام شـد و در

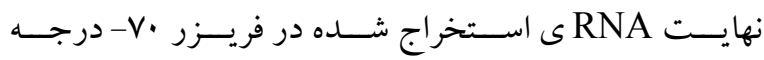
سانتى گر اد نكهدارى شد.

${ }^{7}$ Diethyl Pyrocarbonate (DEPC) ${ }^{8}$ RNase inhibitor
تائيد مدل: جهت اطمينـان از القـاء مـدل كلسـتاز و سـيروز، FA ساعت بعد از جراحى، حيوانات از نظـر رنـك ادرار، بوسـت و سطح بيلى روبين خون (نمونسه خـونى از وريـــ شـكمى كـه در مجاورت آئورت شكمى و در خلف صفاق قـرار دارد، گرفته شد) بررسى شدند. به منظور تائيد القاء مدل سـيروز و مشـاهده شاخصهاى سيروز در بافت كبد، نمونه بردارى از بافت كبـد خــروههـــاى كنتــرل، كلســتاز و ســيروز جهــت مطالعــهـ هيستوياتولوزى به عمل آمل و نمونـههـا در فرمـالين ده درصــ تثبيت شدند. مداخله درمانى: به مدت \& ا روز بعد از شـروع عمل جراحى به صورت روزانه و بر اسـاس وزن هريكك از مـوشهـا مقـدار ه l mg/kg كلستار تحت تيمار و همين مقدار حلال به گرووه كلستاز كنترل (بلدون دريافت لييوئيك اسيد) بـهـورت زيـر جلـدى تزريـق شد(V). همجينين به مدت شش هفته بعد از شروع عمل جراحى كروه سيروز تحت تيمار، محلول لييوئيك اسيد و گروه سيروز كنترل (بدون دريافت لييوئيك اسيد)، حلال را به صورت زيـر جلدى و روزانه دريافت كردند. جمع آورى دادهها: در روز F| يس از عمل جراحى كروههـاى شم و كلستاز و همجنين يس از شش هفته بعد از عمل جراحى كروههاى سيروز، موشهـا بـا تر كيـب كتـامين (ه. mg/kg) و زايلازين( (ه mg/kg) بى هوش شده و ديواره شكمى برش داده شد. سيس از وريد شكمى كه در مجاورت آئورت شكمى و در خلف صفاق قرار دارد دو ميلىليتر خون براى سنجش سطح

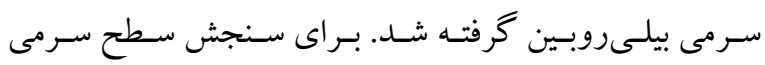
بيلى روبـين از كيـت تشـخيص طبـى (شـركت يـارس آزمـون، ايران) استفاده شد. قبل از نمونه گيرى، يـك ميلىليتـر محلـول RNAlater

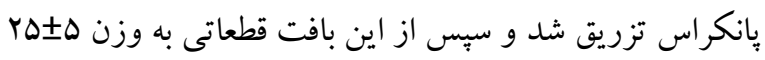

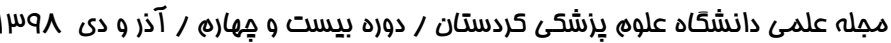




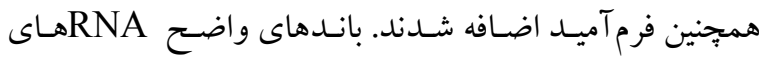
ريبوزومى YAS و MS و نسبت تقريبـى دو بـه يـك بانـدها، بـه عنوان ملاكك سالم بودن RNA ع كل استخراج شـده در نظر كرفته شد(شكل (1).
سنجش كيفى و كمى RNA: به منظور بررسى كيفيـ RNA: ى كـل اسـتخراج شـده، از الكتروفـورز آن بـروى زل آكَارز دناتوره كننده يكك درصـد اسـتفاده شـد. از فرمالدهيـد بعنـوان

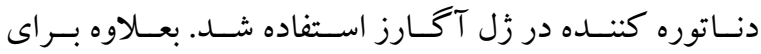
دناتوراسيون RNA ييش از الكتروفورز به نمونهها فرمالدهيد و

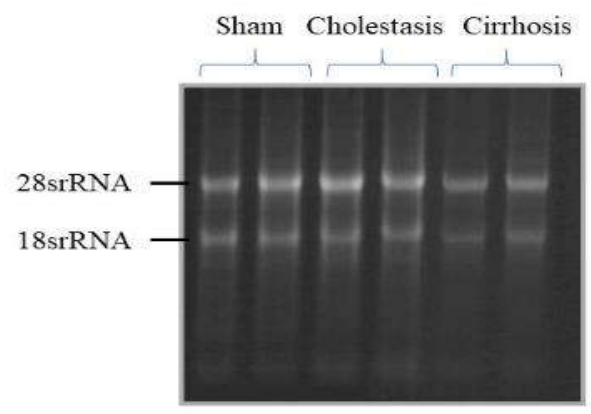

$$
\begin{aligned}
& \text { شكل ا. تصوير زل آكاروز فرمالدهيدى مربوط به RNA هاى استخراج شده } \\
& \text { از بافت يانكر اس موشهاى صحر ايى در گروه آزمايشى تحت مطالعه. }
\end{aligned}
$$

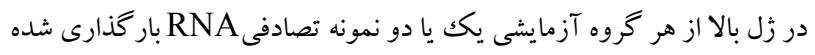

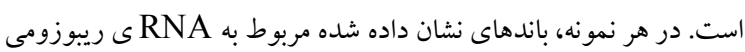

$$
\text { l l و است. TAS }
$$

مراحـل روى يـخ و در زيــر هـود و در شـرايط اسـتريل انجـام

$$
\text { كرفت. }
$$

بررسى تغييرات بيان زن OPA1: در اين تحقيـق بـراى بررسى كمى ميز ان بيان Real- زنهاى مورد مطالعه از روش Time PCR OPA1 ميزان تكثير در جرخهاى كه بيان زن قابل رديـابى اسـت (Ct)

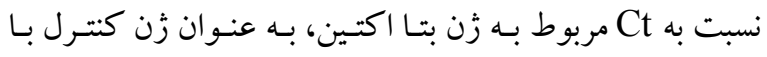

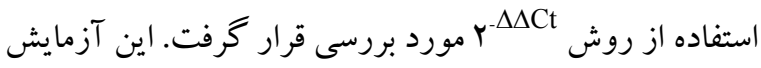
با استفاده از دستگاه لايت سايكلر 99، (شركت رش، آلمـان) و مستر ميكس سايبر گرين "' (شركت تاكارا، زاين) انجام شد.

${ }^{9}$ Cycle Threshold

${ }^{10}$ LightCycler ${ }^{\circledR} 96$ Real Time PCR System

${ }^{11} \mathrm{SYBR}^{\mathrm{TM}}$ Green Master Mix
سـنش كمسى بـر اى تعيـين غلظـت RNA ع كـل، بـه روش اسپيكتروفوتومترى انجام شد و از ميزان جذب بهدست آمده در طـول مـوج • بو نـانومتر بـراى تعيسين غلظـت RNA استخراج شده از نمونهها استفاده شد. ميزان جذب اين نمونههـا

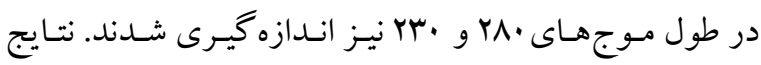

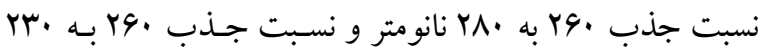
نانومتر ميزان خلوص RNA هاى استخراج شده را نشان داد. ساخت cDNA: غلظت RNA ى استفاده شـده بـراى سـاختن cDNA ميكرو گـرم اسـتفاده شــد. سـاخت cDNA توسـط كيـت PrimeScript ${ }^{\mathrm{TM}}$ RT reagent مطابق روش كار بيشنهادى مو جود در كيت انجام گرفت. كليه

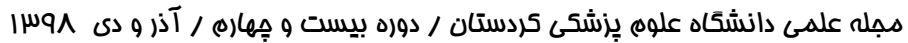


IN4 اثرليِيوائيك اسليد بر...

بافت هاى كبد و يـانكراس و تغييـرات ايجـاد شـده بـهصورت

مقايسه بين گروههاى آزمايشى مورد بررسى قرار گرفت.

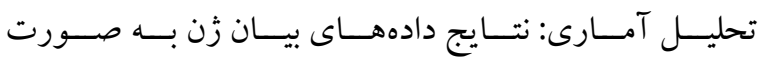

ميانگين 土خطاى استاندارد (SEM) شاخصها در هر گروه بيان

شـد. نتـايج آزمسون كولمـو گروف -اسـميرنوف ها مربسوط بـهـ

اندازه گيرى ميزان بيان زن نشان داد كه توزيع اين دادهها نرمال

نبود، بنابر اين براى تحليل آنهـا از آزمـون كروسـكال-والـيس استفاده گرديد. بس از اينكه معنىدار بودن نتايج با اين آزمـون نشـان داده شـد، بـه منظـور انجـام مقايسـات زوجسى از آزمـون تعقيى و به منظور انجام مقايسات زوجى از آزمون تعقيبى استفاده گر ديـــ. بــراى شـاخص بيلىروبـين از Dunn's test آزمون واريانس يكك طرفه و آزمون تكميلى تـوكى 19 استفاده شد. در همه تحليل ها ه • / > P معنى دار در نظر كرفته شد.
تـو الى mRNA

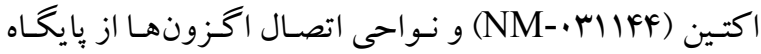
دادهاى NCBI به دست آمـد. جهـت طراحى برايمـر زنهـاى تحت مطالعه از نرمافزار زُنرانر با استفاده شد. سبس با استفاده از ابـزار بلاسـت و يايخـاه دادهاى NCBI از يكتـا بـودن محـل اتصال جفت بر ايمرها و ساختمان فضايى آنها اطمينان حاصل شد. براى جلو گيرى از تكثير احتمالى DNA زنوميكك، يكى

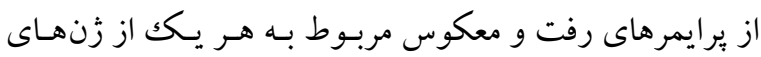
مورد نظر در نواحى اتصال دو اگزون طراحى گرديد كه توالى آنها در جدول آ آورده شده اسـت. سـاخت برايمرهـا توسط شركت سينازن صورت گرفت. به علاوه براى اطمينان از عـدم تكثير احتمالى قطعات DNA زٔنسومى در هنگَام انجـام PCR،

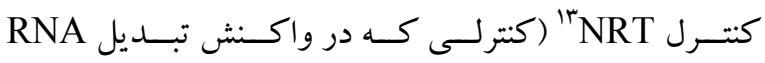
به cDNA از آنزيم نسخهبردار معكوس اسـتفاده نشـده بـود) و كنترل NTC انجام PCR اسـتفاده شـد. عـدم تكثيــر قطعـات مـورد انتظـار و قطعات ديخر در PCR اين نمونه Pــاى كنتـرل، حساكى از عـدم

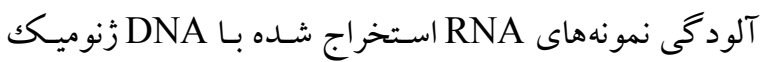

بررسى هيستوياتولوزى پانكراس: براى بررسى تغييـرات بـافتى، برش هاى بافتى پانكراس گرووهاى آزمايشى يس از شستشو در فرمالين ده درصد فيكس شده و بعد از آبكيرى و شفافسازى، نمونهها در داخل پيار افين مذاب قالب گيرى شدند و بـا استفاده از ميكروتوم روتارى (مدل Y DS NF شر كت ديد سبز، ايران) برش هـايى بـا ضـخامت ه ميكـرون تهيـه و بـا هماتو كسيلين -

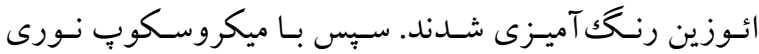

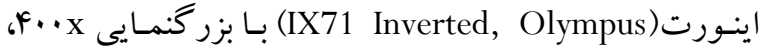

\footnotetext{
${ }^{12}$ Gene Runner

${ }^{13}$ No Reverse Transcriptase

${ }^{14}$ No Template Control
}

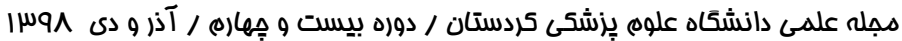


جدول ا. توالى يرايمرهاى طراحى شده براى زنهاى OPA1 و

\begin{tabular}{|c|c|c|c|}
\hline قطعه تكثير شده & 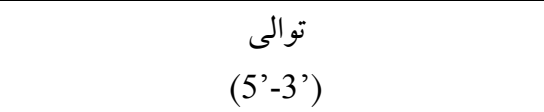 & 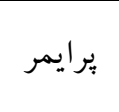 & 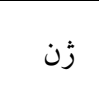 \\
\hline \multirow{2}{*}{$r \cdot q$} & ACGGGTTGTTGTGGTTGGAG & رفت & \multirow{2}{*}{ OPAI } \\
\hline & ACGCTGCAAGATCTTCCTCC & معكوس & \\
\hline \multirow{2}{*}{$r \cdot 1$} & CTGGGTATGGAATCCTGTGG & رفت & \multirow{2}{*}{$\beta$-act } \\
\hline & AGGAGGAGCAATGATCTTGATC & معكوس & \\
\hline
\end{tabular}

با گُروه كنترل، يروليفريشن مجارى صفراوى و آرايش نـامنظم

سـلولهــا را نشــان داد(شـكل Y A و B) ـ همجنــين بررسى هيستوياتولوزى بافـت كبــد مـوشهـاى گـروه سـيروز حضـور مهم ترين شاخص سيروز كبدى يعنى هيبر يلازى شديد مجارى صفراوى و نفوذ بافت همبند كه نشان دهنده رشتههاى كلازن و و

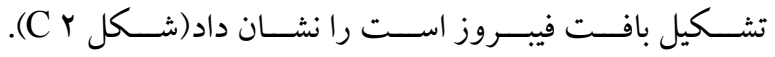

در اين بثزوهش، در مقايسهـ ظـاهر مـوشهـاى صسحرايى گحروه

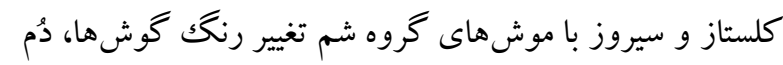

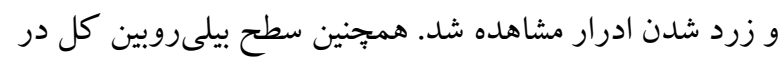

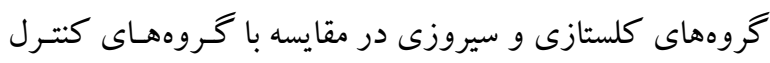
تفاوت معنى دارى نشان داد (F(5, 30)=28.008, P=.000). نتايج مطالعه ميكروسكويى بافت كبد گروه كلستاز در مقايسـه
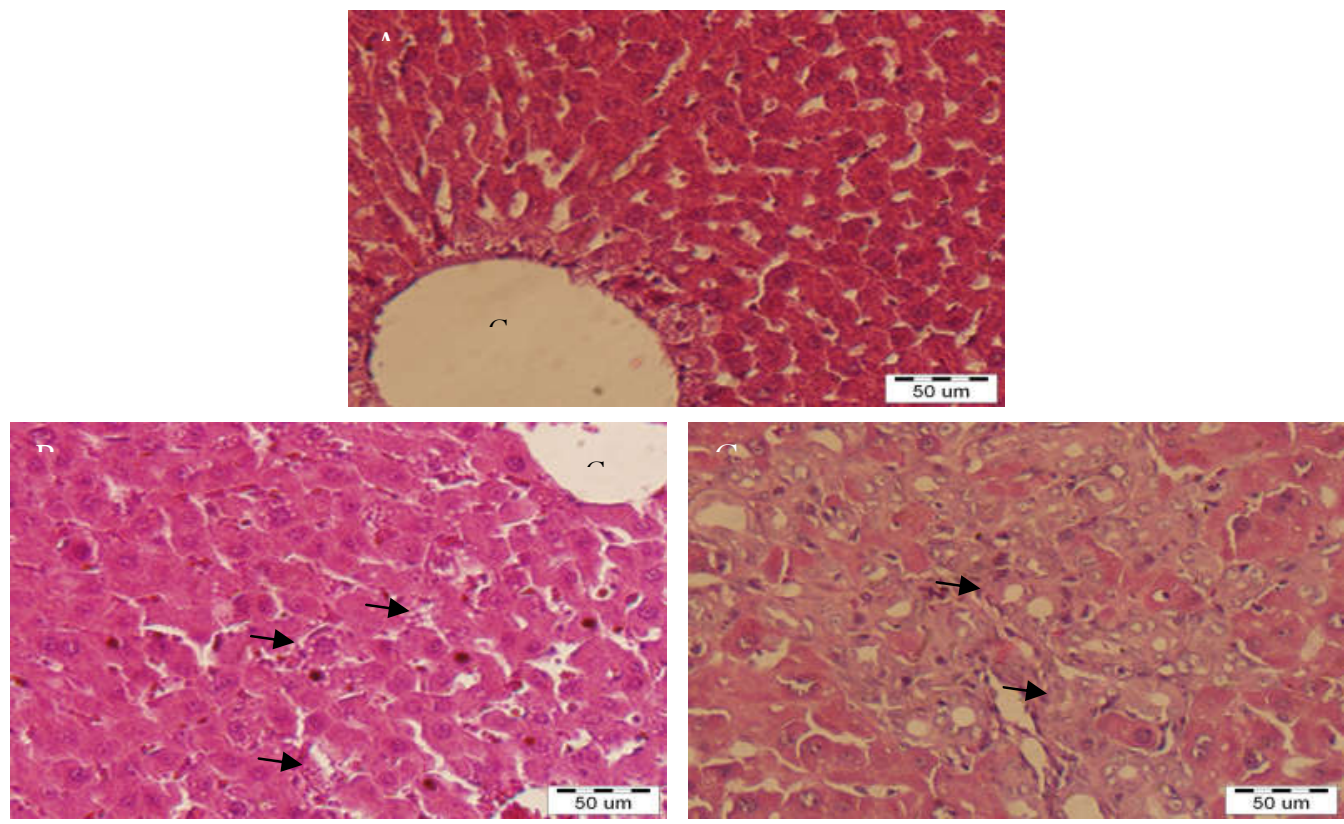

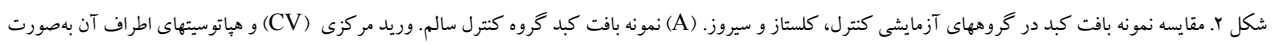

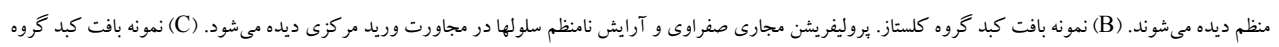

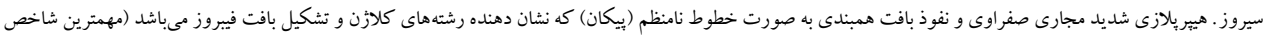

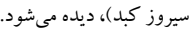

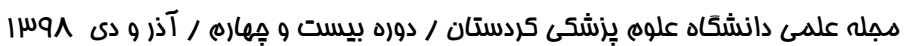


INA

\begin{tabular}{|c|c|}
\hline سيروزى تيمار شده با لييوئيك اسـيد در مقايسـه بـا خـروههـاى & ايـن مشـاهدات موفقيـت آميـز بــودن بروتكـل القـــيى رادر \\
\hline كلسـتازى و ســيروزى تيمـار شــده بــا محلــول سـالين مشــاهده & كروههاى آزمايشى نشان مـدهـــ. تغييـر رنــك ظـاهرى و زرد \\
\hline نشد ( • (P=1/ (جدول Y). & 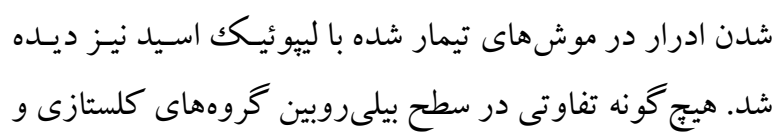 \\
\hline
\end{tabular}

جدول r- نتايج آناليز آمارى دادههاى مربوط به سطح بيلىروبين خون. ستونهاى اول و دوم، مقادير ميانكين و انحراف معيار مربوط به دادههاى كروه هاى

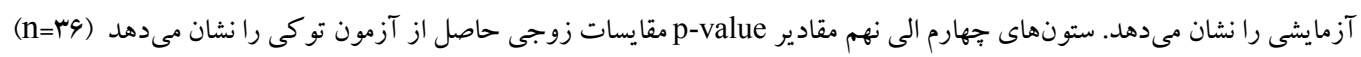

\begin{tabular}{|c|c|c|c|c|c|c|c|c|}
\hline \multicolumn{6}{|c|}{ مقدار p } & \multirow{2}{*}{ انحر اف } & \multirow[t]{2}{*}{ 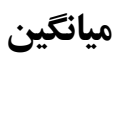 } & \\
\hline سيروز تيمار & سيروز تيمار & كلستاز تيمار & كلستاز & 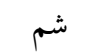 & 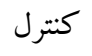 & & & \\
\hline شده با & شده با & شده با & ت ت تيمار شده & & & & & \\
\hline \multirow[t]{7}{*}{ ل ييوئيك اسيد } & 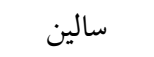 & لييوئيك اسيد & با سالين & & & & & \\
\hline & & & & & & .19 .9 & $r / r)$ & كنترل - \\
\hline & & & & &.$/ 999$ & ./akY & $1 / \wedge V$ & 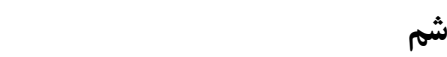 \\
\hline & & & & $\%$ & $\%$ & $r / \cdot \cdot V$ & $\Lambda / \mu_{1}$ & كلستاز تيمار شده با سالين \\
\hline & & & $1 / \cdots$ & $\%$ & $\%$ & $1 / 4 \wedge$ & $\Lambda / F F$ & كلستاز تيمار شده با لييوئيك اسيد \\
\hline & &.$/ 999$ &.$/ 99 \vee$ & $\cdot / \cdot$ &.$/$ & 1/99 & $\Lambda / v r$ & سيروز تيمار شده با سالين \\
\hline & $1 / \cdots$ & $1 / \cdots$ &.$/ 999$ &. &.$/$. & $r / F r$ & $N / 91$ & سيروز تيمار شده با لييوئيك اسيد \\
\hline
\end{tabular}

D Dقاطع بافت پِانكراس در گروه سيروز و در گروه سيروز

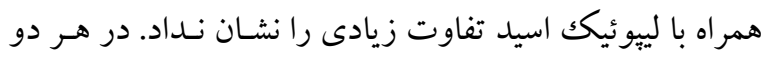

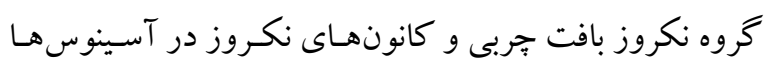
بلهورت وسيع مشاهده شد. در موشهاى سيروزى حوضسجه هاى آسينوسى همر اه با تعداد كم سـلولهــاى آسـينى مشـاهده

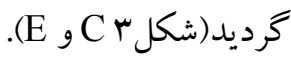

بررسى بـافتى: بررسى مقـاطع ميكروسـكويى بافـت ״ـانكراس

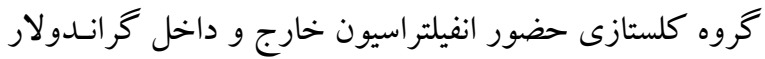

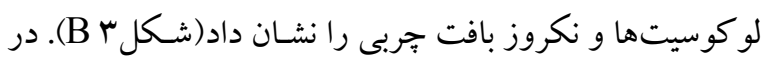

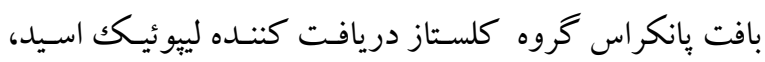

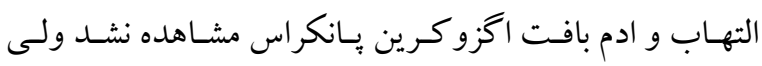

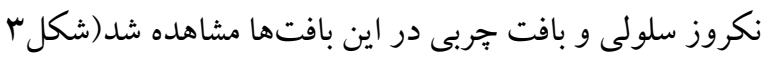




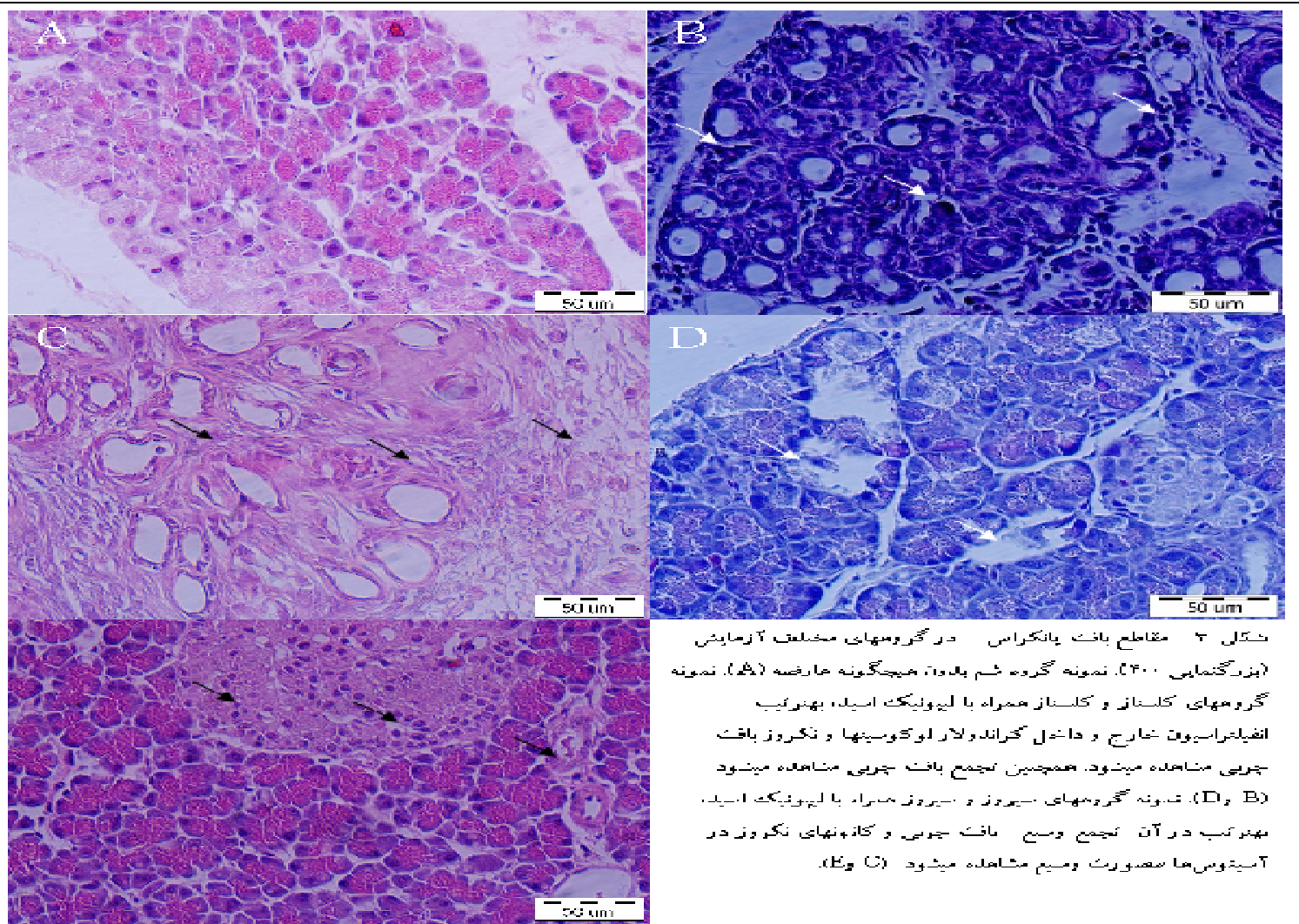

در گروه كلستاز تيمار شده با سالين ديده مسىشود(شكل F).

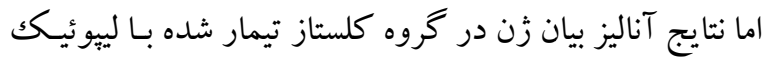

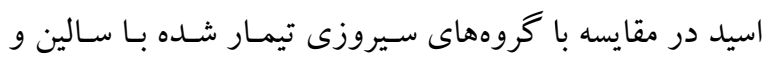
سيروزى تيمار شده با لييوئيك اسيد تفاوت معنىدارى را نشان نداد ( P=1.000). سطح معنى دارى تعديل شده بين دو گ خروه سيروزى نيز معنى دارى نيست (P=1.000).
بررسى بيان زن OPA1. نتايج آزمون كروسكال-واليس مربوط

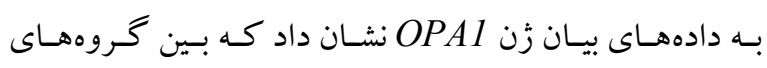
(X) آزمايشى تفاوت معنى P=0.000)

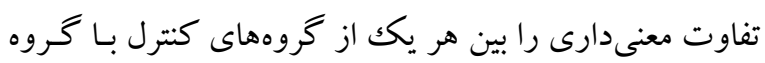

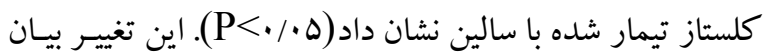

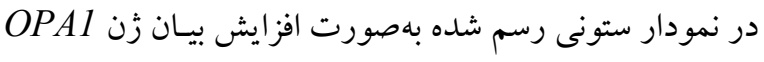

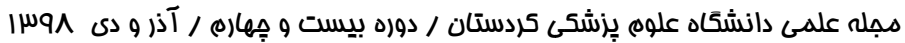




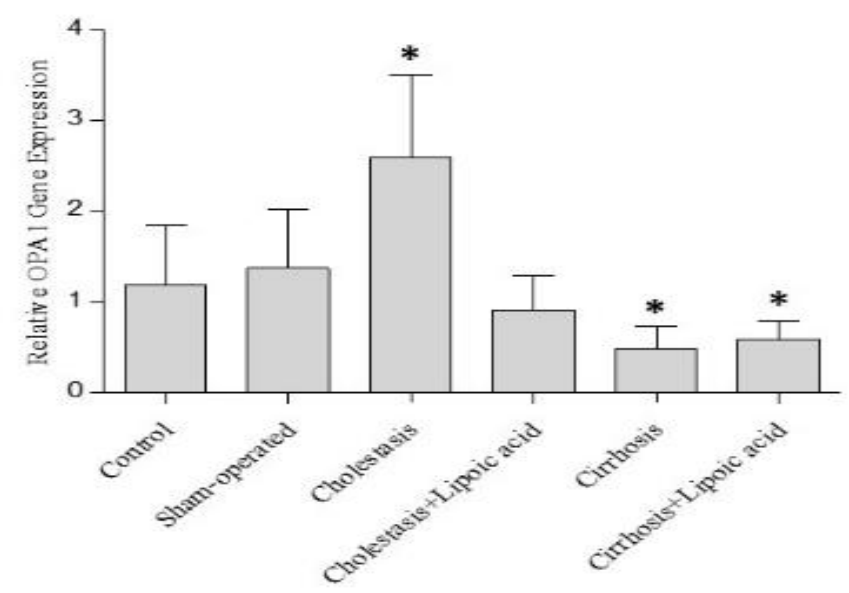

شكل F - نمودار ميزان بيان زن OPA1 در بافت پانكراس گروههاى آزمايشى كنترل، شم، كلستاز، كلستاز تيمارشده با لييوئيك اسيد، سيروز و سيروز تيمارشده با

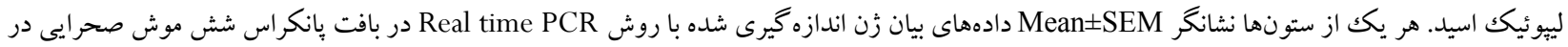

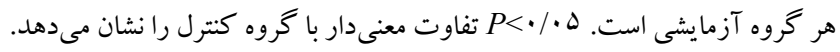

يونهاى فلزى انتقالى را شلاته كرده و ير اكسيداسيون ليبيدها را مهار مى كند. ليّيوئيك اسيد سـطح آنزيمهـاى آنتى اكسـيدانى مانند سويراكسيد ديسموتاز و كلوتاتيون براكسيداز را در كبد، روده و مغـز مـوش هـاى BDL افـزايش مسىدهـد(Vو Y). نتـايج ياتولوزى مطالعه حاضر نشان مـىدهـد كـه نشـانهــاى التهـابى ايجاد شده در بافت پيانكراس موشهاى كلستازى در اثر تيمـار با ليِيويكك اسيد بهبود مىيابد و اين مطالعه براى اولين بار است كه بر روى بافت بـانكر اس انجـام شـده اسـت. كـاهش اثـرات التهابى بافتى بهدست آمده در اين مطالعه با مطالعات ديخر كـه

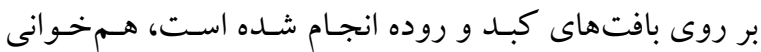
دارد(Y). تجويز خوراكى و يا تزريق لييوئيسك اسـيد منجـر بـهـ تسريع مصرف كلوكز و افزايش حساسيت بافت به انسولين در بيماران مبتلا به ديابت نوع Y شــده اسـت(YF). مطالعـات انجـام شده بر روى مدل حيوانى بيمارى ديابـت نيـز افزايش مصـرف كلوكز و كاهش غلظت لاكتات و ييرووات خون را با مصرف ليبيوئيكك اسـيد نشـان مسىدهـــ. در ايسن مطالعـات در حضسور لييوئيك اسيد كاهش فرايندهاى التهابى در سـلولهـاى جزايـر
تعدادى از محققين عامل ايجاد تخريب در سـلولهـاى آسـينار يانكراس بيمار ان مبتلا به زردى انسدادى را بـه اثـر سيستميكك اسيدهاى صفر اوى مونوهيدرو كسيله مانند TLC-S در داخل سرم و فضاى بين بافتى نسبت مى دهند( آو ووها). در مطالعهاى كه بر روى مدل حيوانى صاريغ آمريكايى انجـام شـده اسـت، شدت بيمارى پانكراتيت القا شده با بستن مجر ایى پانكراس، در صورت همر اه شدن با انسداد مجراى صفراوى شـدت بيشـترى را نشان داده است(سY)؛ بنابر اين نشانه هاى التهابى مشاهده شـده در بافـت بـانكراس مـوشهـاى كلسـتازى و سـيروزى مطالعـه حاضر مى تواند در اثر تجمـع اسـيدهاى صـفر اوى ايجـاد شـده باشد. ليبيوئكك اسـيد بـه عنـوان يـك آنتى اكسـيدان كوفـاكتور در

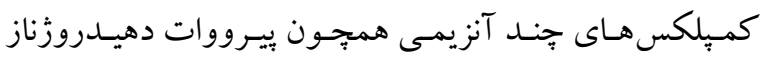
وجود دارد و به طور قابل توجهى غلظت كلو تاتيون احياءشـده را در كبـد حيوانـات BDL افـزايش مسىدهـد. عـلاوه بـر آن،

${ }^{17}$ Taurolithocholic acid 3 sulfate

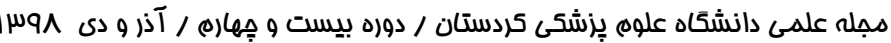


به هسته به منظور ايفاى نقش آن بهعنوان فعال كننده رونويسى مى شود. در شرايط طبيعى تعـدادى از يـروتئين هـاى STATY در ميتو كنـدرى مسـتقر هسـتند (mitoSTATr) و در كنتـرل عملكردهاى ميتو كندرى نقـش دارنـد. تحـت شـرايط اسـترس اكسيداتيو و توليد مقدار زياد راديكالهاى آزاد، يتانسيل غشـاء ميتو كندرى كاهش مىيابد. اين امر باعث ناتوانى ماشين انتقـال يروتئين ها به داخل ميتو كندرى شـده و منجـر بـه جـذب بيشـتر يروتئين هاى سئ STATY به طرف هسته براى ايفاى نقش ديخـر آنها بهعنوان فاكتور رونويسى مىشود(Yq). با توجه به مطالب ذكر شـده مسى تـوان نقـش دو فـاكتور رونويسى NF-кB و م - را در كنترل بيان زن OPA1 در بافت پيانكراس موش STAT هـاى كلسـتازى بيشـنهاد داد. از يـكك سـو در شـرايط افـزايش استرس اكسيداتيو ناشى از تجمع اسيدهاى صفراوى و افزايش يروتئين س STAT در هسته و از سوى ديكر فعـال شـدن مسـير NF-אيكنالى التهابى و افززايش فعاليـت فـاكتور رونويسى مسى توانسـ منجـر بــه افـز ايش بيـان زن OPA1 در سـلولهــاى يانكر اس شود تا اين سلولها بتوانند بـراى حفـظ حيـات خـود، عملكـرد و سـاختار ميتو كنـدرى را تـرميم كننـد. در مطالعـات كذشـته در درون هسـته ارتبـاط فيزيكى بـين ايسن دو فـاكتور

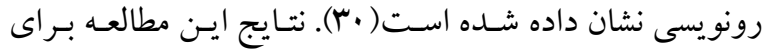
اولين بار در گيرى مسير سيخنالى مـرتبط بـا بيـان زن OPA1 در يانكراتيت ناشى از كلستاز نشان مىدهد. با كـاهش اسـترس اكسيداتيو در حضور لييوئيك اسيد در موشهاى كلستازى اين افزايش بيان ديلده نمى شـود كـه ايسن نتيجـه مسى توانــ ناشـى از باز گشت طبيعى بيتانسـيل غشـاء ميتو كنـدرى و كـاهش ميـزان فاكتور رونويسى سكTAT باشد. اين نتايج نشان مسىدهـ كـه در ياتولوزى كلستاز استرس اكسيداتيو ايجاد شده در اثر تجمع اسيدهاى صفراوى مى تواند مسير سيخنالى بيان زنهـاى دخيـل

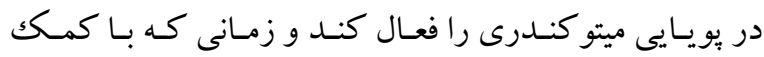

يانكراس مشاهده شده است(YD). همجيخين اثرات بهبـود بخـش ليجيوئك اسيد بر روى مدل حيوانى پِانكراتيت حساد نشـان داده

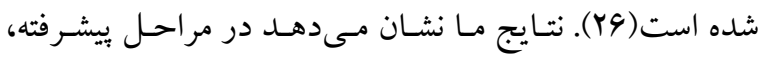
اثرات بهبود بخش لييوئيك اسيد در التهاب ايجاد شدهى ناشى از انسداد مجراى صفراوى ديده نمى شود. در مطالعه حاضر در موشهاى كلسـتازى افزايش معنسىدار زّن OPA1 مستقيم اسيدهاى صفراوى بر روى سلولهاى آسينى بـانكراس مـوش و آزاد شــدن نوسـانى Ca از ذخـاير داخـل سـلولى را نشـان مسىدهـد(f). افـزايش كلسـيم سيتويلاسـمى ناشـى از اسيدهاى صفر اوى، در سلولهاى بانكراس رت منجر بـه فعـال شدن سيخنالهاى التهابى ناشى از كينازهـاى c-Jun و فـاكتور رونويسى NF-KB مى شود(YV). در شرايط استرس در سـلولهاى يانكراس موش براى جلو گيرى از دست دادن بـيش ازحـد ميتو كندرىهاى سلول و برقرارى تعـادل و حفـظ تماميـت ايـن اندامكك، مسير TNF $\alpha-N F \kappa B-O P A 1$ فعال مىشود. بـه ايـن

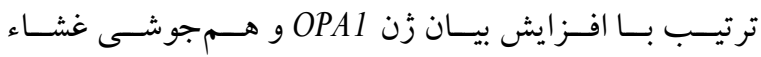
ميتو كندرى، ساختار تيغههـاى ميـانى آن بهبـود يافتـه و تـنفس سلولى با كارايى بهترى انجام مىشود(YN)؛ بنابر اين در مطالعه حاضر افزايش بيان زن OPA1 و حضور علائم التهاب بافتى در بافت يانكراس موش هاى كلسـتازى بـا مطالعـات كذشـته هـم خوانى دارد و مىتواند فعال شدن مسير سيخنالى فـوق را تائيـد كند. از سوى ديخر در مطالعهاى كه اخيراً بر روى مسـير بيـامرسانى تنظيم كننده بيان زن OPA1 در شـرايط اسـترس انجـام

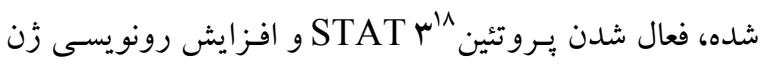
OPA1 عملكردهاى فيزيولوزيكك و ياتولوزيك مـرتبط اسـت و فسـفر يله شدن آن در حضور سيتو كينها منجر به انتقال اين يسروتئين

${ }^{18}$ Signal Transducer and Activator of Transcription 3

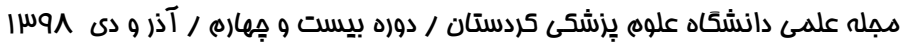


رسرا اثرليِيوئيك اسيد بر...

يشنهاد: براى شناخت بهتر سازو كار سيخنالى در گيـر در مسـير

كلستاز بيشــهاد مسىشـود كـه در مـوش هـاى كلسـتازى ميـزان

حضور يـروتئين هـاى م STAT وNFkB در حضـور و عـدم حضور لييوئك اسيد مورد بررسى قرار بـيرد.

محدوديت: بر اساس اهداف طراحى شـده در برويـوزال بايـان

نامه محدوديتى در انجام يروزه بهوجود نيامد.

\section{نتيجه Fيرى}

تغيير بيان زن OPA1 در بافت يانكراس موش هاى صحرايى بـا

انسداد مجر اى صفر اوى مى تواند نقـش بيويـايى ميتو كنـدرى را

در آسيبشناسى اين عارضه نشان دهـد. اثر ليبوئيكك اسـيد در

تغييرات بيان زن OPA1 نشان دهنده تـأثير اسـترس اكسـيداتيو

در مسير سيخنالى عارضه كلستاز است.

\section{تشكر و قدردانى}

نتايج جابِ شده در اين مقالـه از طـرح يايسان نامـه كارشناسى

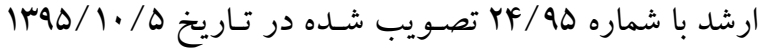
استخراج شده است. بدينوسـيله نويسـند گان ايسن مقاله مراتـب تشكر و قدردانى خود را از معاونـت يثزوهشى دانشـكده علـوم دانشگاه كردستان و مركز تحقيقـات كـوارش و كبـد دانشـاه

$$
\text { علوم يزشكى كردستان اعلام مى دارند. }
$$

ليجيويكك اسيد اين استرس كنترل مى شود فعال شدن ايسن مسـير سيخنالى مشاهده نمى شود. نتايج مربوط به بيان زن و مطالعـات ياتولوزيكى در مرحله سـيروز نشـان مسىدهـد كـه در مراحل بيشرفته بيمارى علائم يـاتولوزيكى انسـداد صـفراوى در بافـت يانكراس تشديد شده و حتى در حضور ليِيوئيك اسيد هم ايسن علائم ديده مىشوند. همجنـين در ايسن شـرايط ميزان بيـان زن OPA1 حالت طبيعى است. اين نتايج تغيير مسير سيكنالى فعال شده در روند بيشرفت كلستاز را نشان مىدهد. نتايج مطالعات كذشته ما فعال شدن بيان زن DRP1 رادر كبد موش هاى كلستازى نشـان مى دهد(9). با در نظر گرفتن اين يافتها مىتوان نتيجه گرفت

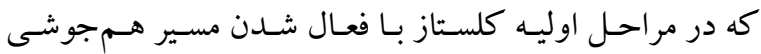
ميتو كندرى، سلول در صدد مبارزه با افزايش استرس اكسيداتيو و آيويتوز برمى آيد اما در مراحل بيشرفته و سيروز، بـا افزايش آسيب وارده به ميتو كندرىهاى سلول، مسـير سـيخنالى كنتـرل كننده استرس اكسيداتيو تغيير كرده و احتمـالاً افزايش فراينـد شكافت غشايى ميتو كندرى كه در تضاد بـا هـم جوشى اسـت، سلول را بـه طرف آيويتـوز هـدايت مسى كنـد. در ايسن مرحله. حضور لييوئيك اسيد هم نمى تواند جلـوى بيشـرفت التهاب و مر گك سلولى را بخيرد.

\section{References}

1. Arduini A, Serviddio G, Tormos AM, Monsalve M, Sastre J. Mitochondrial dysfunction in cholestatic liver diseases. 2012.

2. Somi M, Kalageychi H, Hajipour B, Musavi G, Khodadadi A, Shokri N, et al. Lipoic acid prevents hepatic and intestinal damage induced by obstruction of the common bile duct in rats. Eur Rev Med Pharmacol Sci. 2013;17(10):1305-10.

3. Arduini A, Serviddio G, Escobar J, Tormos AM, Bellanti F, Viña J, et al. Mitochondrial biogenesis fails in secondary biliary cirrhosis in rats leading to mitochondrial DNA depletion and deletions. American Journal of Physiology-Gastrointestinal and Liver Physiology. 2011;301(1):G119-G27. 
فرنوش فسروبخش

4. Voronina S, Longbottom R, Sutton R, Petersen OH, Tepikin A. Bile acids induce calcium signals in mouse pancreatic acinar cells: implications for bile $\square$ induced pancreatic pathology. The Journal of physiology. 2002;540(1):49-55.

5. Voronina SG, Barrow SL, Gerasimenko OV, Petersen OH, Tepikin AV. Effects of secretagogues and bile acids on mitochondrial membrane potential of pancreatic acinar cells comparison of different modes of evaluating $\Delta \Psi \mathrm{m}$. Journal of Biological Chemistry. 2004;279(26):27327-38.

6. Voronina SG, Gryshchenko OV, Gerasimenko OV, Green AK, Petersen OH, Tepikin AV. Bile acids induce a cationic current, depolarizing pancreatic acinar cells and increasing the intracellular $\mathrm{Na}+$ concentration. Journal of Biological Chemistry. 2005;280(3):1764-70.

7. Zakaria M, Hajipour B, Taghizadieh M, Mousavi G, Khodadadi A. Lipoic acid attenuates cholestasis induced cerebral injury in rats. Life Science Journal. 2013;10(SUPPL.):539-45.

8. Yu T, Wang L, Lee H, O'Brien DK, Bronk SF, Gores GJ, et al. Decreasing mitochondrial fission prevents cholestatic liver injury. Journal of Biological Chemistry. 2014:jbc. M114. 588616.

9. Khosrobakhsh F, Moloudi MR, Bigdelo M, Rahimmi A. Effect of cholestasis on DynaminRelated Protein 1 (Drp1) gene expression in rat liver. Scientific Journal of Kurdistan University of Medical Sciences. 2017;22(4):68-79.

10. Belenguer P, Pellegrini L. The dynamin GTPase OPA1: more than mitochondria? Biochimica et Biophysica Acta (BBA)-Molecular Cell Research. 2013;1833(1):176-83.

11. Delettre C, Lenaers G, Griffoin J-M, Gigarel N, Lorenzo C, Belenguer P, et al. Nuclear gene OPA1, encoding a mitochondrial dynamin-related protein, is mutated in dominant optic atrophy. Nature genetics. 2000;26(2):207.

12. Delettre C, Griffoin J-M, Kaplan J, Dollfus H, Lorenz B, Faivre L, et al. Mutation spectrum and splicing variants in the OPA1 gene. Human genetics. $2001 ; 10.91-\Delta \wedge \uparrow:\left({ }^{9}\right)^{q}$

13. Akepati VR, Müller EC, Otto A, Strauss HM, Portwich M, Alexander C. Characterization of OPA1 isoforms isolated from mouse tissues. Journal of neurochemistry. 2008;106(1):372-83.

14. Olichon A, Emorine LJ, Descoins E, Pelloquin L, Brichese L, Gas N, et al. The human dynamin $\square$ related protein OPA1 is anchored to the mitochondrial inner membrane facing the inter $\square$ membrane space. FEBS letters. 2002;523(1-3):171-6.

15. Chen H, Chomyn A, Chan DC. Disruption of fusion results in mitochondrial heterogeneity and dysfunction. Journal of Biological Chemistry. 2005;280(28):26185-92.

16. Frezza C, Cipolat S, De Brito OM, Micaroni M, Beznoussenko GV, Rudka T, et al. OPA1 controls apoptotic cristae remodeling independently from mitochondrial fusion. Cell . .A9-1VV:(1) 1 Y $9 ; \%$. 9

17. Reinhardt F, Schultz J, Waterstradt R, Baltrusch S. Drp1 guarding of the mitochondrial network is important for glucose-stimulated insulin secretion in pancreatic beta cells.

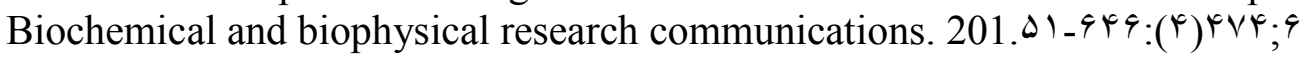

18. Zhang Z, Wakabayashi N, Wakabayashi J, Tamura Y, Song W-J, Sereda S, et al. The dynamin-related GTPase Opal is required for glucose-stimulated ATP production in pancreatic beta cells. Molecular biology of the cell. 2011;22(13):2235-45.

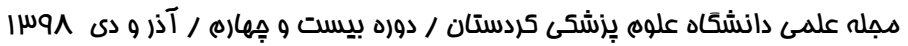


عاسرا اثرليبِيويك اسيد بر...

19. Bosoi CR, Oliveira MM, Ochoa-Sanchez R, Tremblay M, Ten Have GA, Deutz NE, et al. The bile duct ligated rat: A relevant model to study muscle mass loss in cirrhosis. Metabolic brain disease. 2017;32(2):513-8.

20. Dastgheib S, Irajie C, Assaei R, Koohpeima F, Mokarram P. Optimization of RNA extraction from rat pancreatic tissue. Iranian journal of medical sciences. 2014;39(3):282.

21. Ahmadi S, Karami Z, Mohammadian A, Khosrobakhsh F, Rostamzadeh J. Cholestasis induced antinociception and decreased gene expression of MOR1 in rat brain. Neuroscience. 2015;284:78-86.

22. Lerch MM, Aghdassi AA. The role of bile acids in gallstone-induced pancreatitis. Gastroenterology. 2010;138(2):429-33.

23. Senninger N, Moody FG, Coelho JC, Van Buren DH. The role of biliary obstruction in the pathogenesis of acute pancreatitis in the opossum. Surgery. 1986;99(6):688-93.

24. Bilska A, Wlodek L. Lipoic acid-the drug of the future. Pharmacol Rep. 2005;57(5):570-7.

25. Berkson BM. A conservative triple antioxidant approach to the treatment of hepatitis C. Medizinische Klinik. 1999;94(3):84-9.

26. Abdin AA, El-Hamid MAA, El-Seoud SHA, Balaha MF. Effect of pentoxifylline and/or alpha lipoic acid on experimentally induced acute pancreatitis. European journal of pharmacology. $94-r \wedge 9:(r-r)^{9} \uparrow r ; r \cdot 1 \cdot$.

27. Kim JY, Kim KH, Lee JA, Namkung W, Sun AQ, Ananthanarayanan M, et al. Transportermediated bile acid uptake causes $\mathrm{Ca} 2+$-dependent cell death in rat pancreatic acinar cells. Gastroenterology. 2002;122(7):1941-53.

28. Baltrusch $\mathrm{S}$.Mitochondrial network regulation and its potential interference with inflammatory signals in pancreatic beta cells. Diabetologia. 2016;59(4):683-7.

29. Meier JA, Hyun M, Cantwell M, Raza A, Mertens C, Raje V, et al. Stress-induced dynamic regulation of mitochondrial STAT3 and its association with cyclophilin D reduce mitochondrial ROS production. Sci Signal. 2017;10(472):eaag2588.

30. Kesanakurti D, Chetty C, Maddirela DR, Gujrati M, Rao JS. Essential role of cooperative $\mathrm{NF}-\kappa \mathrm{B}$ and Stat3 recruitment to ICAM-1 intronic consensus elements in the regulation of radiation-induced invasion and migration in glioma. Oncogene. 2013;32(43):5144. 